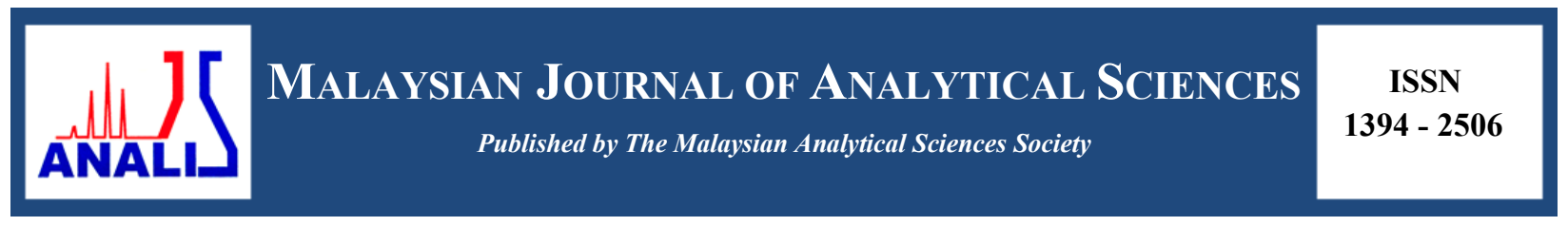

\title{
DETERMINATION OF OPTIMUM CONDITIONS AND STABILITY STUDY OF BIOSURFACTANT PRODUCED BY Bacillus subtilis UKMP-4M5
}

\author{
(Penentuan Keadaan Optimum dan Kajian Kestabilan Biosurfaktan yang Dihasilkan oleh \\ Bacillus subtilis UKMP-4M5)
}

\author{
Ummul Khair Mohd Syahriansyah and Ainon Hamzah* \\ School of Biosciences and Biotechnology, Faculty of Science and Technology, \\ Universiti Kebangsaan Malaysia, 43600 UKM Bangi, Selangor Darul Ehsan, Malaysia \\ *Corresponding author: ainonh@gmail.com
}

Received: 29 January 2016; Accepted: 17 June 2016

\begin{abstract}
Bacillus subtilis UKMP-4M5 was isolated from a hydrocarbon contaminated site which was found to be the most potential biosurfactant producer. Isolates were grown in a mineral salt medium (MSM) supplemented with sunflower oil (1\% v/v) as the main carbon source. Screening was based on both qualitative (oil spreading technique) and quantitative (emulsification index and surface tension measurement) methods. B. subtilis UKMP-4M5 produced the highest oil displacement activity with and emulsification index of $17 \%$. It also reduced surface tension of culture medium from 58.95 to $41.75 \mathrm{mN} / \mathrm{m}$. B. subtilis UKMP4M5 produced biosurfactant with surface tension measurement of $32.7 \pm 0.66 \mathrm{mN} / \mathrm{m}$ using $2 \%(\mathrm{v} / \mathrm{v})$ palm oil and $0.5 \%(\mathrm{w} / \mathrm{v})$ yeast extract as carbon and nitrogen sources respectively. The tested biosurfactant exhibited excellent thermal (up to $120{ }^{\circ} \mathrm{C}$ ) and $\mathrm{pH}(6.0-8.0)$ stability as well as high tolerance for varying salt concentrations $(1-5 \% \mathrm{w} / \mathrm{v})$ in terms of surface tension reducing ability. This suggests potential applications in fields such as enhanced oil recovery, bioremediation, and the food industry.
\end{abstract}

Keywords: Bacillus subtilis, biosurfactant, palm oil, surface tension

\section{Abstrak}

Bacillus subtilis UKMP-4M5 yang dipencilkan dari kawasan yang tercemar dengan hidrokarbon didapati paling berpotensi sebagai penghasil biosurfaktan. Pencilan dihidupkan di dalam medium garam mineral (MSM) yang ditambahkan dengan 1\% (i/i) minyak bunga matahari sebagai sumber karbon utama. Penyaringan adalah berdasarkan kepada kedua-dua kaedah kualitatif (teknik penyebaran minyak) dan kuantitatif (indeks emulsifikasi dan ukuran ketegangan permukaan). B. subtilis UKMP-4M5 merekodkan aktiviti sesaran minyak yang tertinggi dengan indeks emulsifikasi sebanyak 17\%. Ia juga merendahkan ketegangan permukaan kultur medium dari $58.95 \mathrm{mN} / \mathrm{m}$ ke $41.75 \mathrm{mN} / \mathrm{m} \mathrm{B}$. subtilis UKMP-4M5 menghasilkan biosurfaktan dengan ukuran ketegangan permukaan $32.7 \pm 0.66 \mathrm{mN} / \mathrm{m}$ menggunakan $2 \%$ (i/i) minyak kelapa sawit dan $0.5 \%$ (b/i) ekstrak yis masing-masing sebagai sumber karbon dan nitrogen. Biosurfaktan yang diuji menunjukkan kestabilan yang amat baik pada suhu (sehingga $\left.120{ }^{\circ} \mathrm{C}\right)$ dan $\mathrm{pH}(6.0-8.0)$ serta toleransi yang tinggi pada kepekatan garam yang berbeza $(1-5 \%$ b/i) dari segi keupayaannya merendahkan ketegangan permukaan. Ini mencadangkan potensi aplikasinya dalam industri seperti peningkatan perolehan minyak, bioremediasi dan industri makanan.

Kata kunci: Bacillus subtilis, biosurfaktan, minyak kelapa sawit, ketegangan permukaan

\section{Introduction}

Biosurfactants are amphiphilic molecules containing hydrophobic and hydrophilic moieties. They are produced by a variety of microorganisms such as yeasts, fungi, and bacteria. A majority of these molecules are produced by 
bacteria which are able to interact between two immiscible interfaces, such as water-oil or water-air phases. Bacillus subtilis, for example, produces lipopeptide surfactin, a powerful biosurfactant that can reduce surface tension of water from $72 \mathrm{mN} / \mathrm{m}$ to $27 \mathrm{mN} / \mathrm{m}$ at a concentration of $0.05 \%$ [1]. Other lipopeptide biosurfactants synthesised by Bacillus sp. include iturin [2] and fengycin [3].

Many organisms produced biosurfactants which metabolise water-immiscible substrates such as hydrocarbons and vegetable oil, thus increasing bioavailability and allowing for their adsorption, emulsification, and dispersion. Furthermore, the ability to reduce surface tension is a major characteristic of a surfactant which has potential applications in many consumer and industrial products such as shampoos, detergents, and toothpaste. Other potential applications include enhanced oil recovery, bioremediation, pharmaceuticals, cosmetics, and food-related industries. In comparison with the current widely used chemical surfactants, biosurfactants offer several advantages such as lower toxicity, higher biodegradability, and effectiveness at extreme temperatures and $\mathrm{pH}$ values [1].

Although promising, biosurfactants in general cannot compete with their chemically synthesised counterparts in the surfactant market mainly due to their high production costs. Thus the attention is now geared to the need for costeffective processes and the use of inexpensive substrates, as these can reduce overall production costs up to $30 \%$ [1]. Optimisation of culture conditions for maximum biosurfactant production would also be among the strategies employed by researchers for the purpose of cost reduction. Studies on the biosurfactant production by Bacillus sp. have been performed using water-soluble substrates such as glucose [4] and glycerol [5] as well as water immiscible substrates such as diesel oil [6]. Other substrates such as molasses were also used for the production of biosurfactants by Bacillus subtilis [7]. Others have reported the optimization of culture conditions such as $\mathrm{pH}$ and temperature on bacterial cell growth which in turn affecting biosurfactant production [8].

Identification of a newly-found bacterium strain capable of producing a biosurfactant combined with use of cheap substrates for growth medium could give a promising future to biosurfactant to become economically competitive in the surfactant industry. Therefore, the objectives of this study were to screen and identify potential biosurfactantproducing bacteria, determine the best culture conditions for increased production of biosurfactants, and carry out a stability study of the biosurfactant produced.

\section{Bacterial culture}

\section{Materials and Methods}

Twenty five bacterial isolates were obtained from culture collection in Microbiology laboratory, School of Biosciences and Biotechnology, Faculty of Science and Technology, Universiti Kebangsaan Malaysia.

\section{Preparation of standard inoculum}

The amount of bacteria was standardized as described by Hamzah et al. [9] in order to obtain the same number of bacteria for all the tests.

\section{Screening methodology for biosurfactant production}

Approximately $10 \%(\mathrm{v} / \mathrm{v})$ of standard inoculum from each isolate were grown in a $250 \mathrm{~mL}$ Erlenmeyer flask containing $50 \mathrm{~mL}$ of mineral salt medium (MSM) [10] supplemented with $1 \%(\mathrm{v} / \mathrm{v})$ sunflower oil as a carbon source. The $\mathrm{pH}$ value of the medium was adjusted to 7.0 and the cultures were incubated in shaking condition at $150 \mathrm{rpm}, 37^{\circ} \mathrm{C}$ for 5 days. Biosurfactant production was tested from the cell-free culture supernatant obtained via centrifugation at $15000 \mathrm{rpm}$ for 20 mins at $4{ }^{\circ} \mathrm{C}$ (RC5C Sorvall Centrifuge Instrument, USA).

\section{Screening of biosurfactant producer}

Potential biosurfactant producing bacteria were screened via both qualitative (oil spreading technique) and quantitative (emulsification index and surface tension measurement) methods. In the oil spreading technique, the test method was carried out according to Yousseff et al. [11]. Tapis crude oil $(15 \mu \mathrm{L})$ was added to a Petri dish containing $50 \mathrm{~mL}$ of distilled water. Then, $10 \mu \mathrm{L}$ of cell-free culture supernatant was dropped onto the surface of oil. Formation of a clear zone indicates the presence of biosurfactant. The diameter of oil displaced was measured in $\mathrm{cm}$. 
The emulsification index was determined according to Cooper and Goldenberg [12]. Cell-free culture supernatant and Tapis crude oil $(1: 1, \mathrm{v} / \mathrm{v})$ were mixed in a test tube and vortexed at high speed for $2 \mathrm{~min}$. After $24 \mathrm{~h}$ of incubation at room temperature, the emulsification index $\left(\% \mathrm{E}_{24}\right)$ was determined. Isolates that give high emulsification index indicates high emulsification activity of the biosurfactant produced.

The surface tension of cell-free culture supernatant was measured using a tensiometer (Surface Tensiomat, Fisher Scientific, USA) following the Du Nouy ring method [13]. An isolate that is able to reduce surface tension $<40 \mathrm{mN} / \mathrm{m}$ is regarded as the potential biosurfactant producer [14]. Sodium dodecyl sulphate (SDS) and MSM only were used as positive and negative controls, respectively. The selected potential biosurfactant producers will be used for identification.

\section{Identification of biosurfactant-producing bacteria}

Potential biosurfactant-producing bacteria were identified based on morphological (including Gram reaction) and biochemical characteristics. Isolates were further identified by $16 \mathrm{~S}$ rDNA analysis. Bacterial DNA was extracted via a nucleic acid extraction kit (Macherey-Nagel, Germany) according to manufacturer's instruction and amplified by polymerase chain reaction (PCR) using universal primers (p16Sf: 5'-AGAGTTTGATCCTGGCTCAG-3'; p16Sr: 5'-GGTTACCTTGTTACGACTT-3'). The PCR products were purified with a PCR purification kit (MachereyNagel, Germany) and sent for sequencing analysis to First Base Laboratories Sdn. Bhd. The resulting sequences were compared with sequences in the GenBank database of NCBI using the BLAST network service.

\section{Determination of the best carbon and nitrogen sources for biosurfactant production}

The best carbon and nitrogen sources for increased biosurfactant production by the test bacteria was determined by the lowest surface tension value of the cell-free culture supernatant. Different types of carbon and nitrogen sources were evaluated for production of biosurfactants, followed by determining the optimum concentration of each source. For the following experiments, $10 \%(\mathrm{v} / \mathrm{v})$ of standard inoculum was inoculated in a $250 \mathrm{~mL}$ Erlenmeyer flask containing $50 \mathrm{~mL}$ MSM. pH of the medium was adjusted to (7.0). The broth cultures were incubated with shaking condition at $150 \mathrm{rpm}, 37^{\circ} \mathrm{C}$ for 5 days. Production of biosurfactant was monitored by determining the surface tension value of the cell-free culture supernatant, via du Nouy ring method using a tensiometer. Measurements were performed in triplicate.

Five different carbon sources, namely crude oil, glycerol, molasses, palm oil, and palm oil mill effluent (POME) were used at $1 \%(\mathrm{v} / \mathrm{v})$ added to MSM for for increased production of biosurfactant. The best carbon source will be selected based on the lowest surface tension value and used for determining optimum concentration, which may range from 0.5 to $3 \%(\mathrm{v} / \mathrm{v})$.

Four nitrogen sources (ammonium chloride $\left(\mathrm{NH}_{4} \mathrm{Cl}\right)$, ammonium nitrate $\left(\mathrm{NH}_{4} \mathrm{NO}_{3}\right)$, peptone and yeast extract) were evaluated for increased production of biosurfactant, maintaining equal amount of total nitrogen in each media at $24.21 \%$. For the evaluation of the most optimum nitrogen concentration, the selected nitrogen source was varied from 0.1 to $0.8 \%(\mathrm{w} / \mathrm{v})$. The selected carbon and nitrogen sources at their optimum concentration will be used in the subsequent experiments.

\section{Stability studies}

Stability studies were carried out using extracted biosurfactant which was carried out via acid precipitation followed by solvent extraction method [7].

To study the effects of $\mathrm{pH}$ on biosurfactant activity, equal volumes of extracted biosurfactant $(1 \% \mathrm{w} / \mathrm{v}$ in distilled water) and buffer solution were mixed and adjusted to $\mathrm{pH} 2-5$ using citrate-phosphate buffer, $\mathrm{pH} 6-8$ using phosphate buffer, and $\mathrm{pH} 9-12$ using carbonate-bicarbonate buffer solutions and incubated for $30 \mathrm{~min}$. at room temperature before measuring surface tension using a tensiometer.

For the thermal stability study, extracted biosurfactant was used to prepare biosurfactant solutions $(1 \% \mathrm{w} / \mathrm{v})$ in $0.1 \mathrm{M}$ phosphate buffer solution ( $\mathrm{pH}$ 7). Test tubes containing biosurfactant solutions were incubated at different 
temperatures $\left(10,20,30,40,50,60,70,80,90,100{ }^{\circ} \mathrm{C}\right)$ for 1 hour, then autoclaved at $121{ }^{\circ} \mathrm{C}$ for $15 \mathrm{~min}$. Test solutions were allowed to cool to room temperature before measuring surface tension.

A stability study at different salinity levels was performed by adding extracted biosurfactant $(1 \% \mathrm{w} / \mathrm{v})$ into sodium chloride $(\mathrm{NaCl})$ solution at different concentrations $(2-10 \% \mathrm{w} / \mathrm{v})$. Surface tension was determined after incubation for 1 hour at room temperature.

\section{Statistical analysis}

The results are represented as the mean \pm standard deviation from at least three replicates. One-way analysis of variance was performed on surface tension data to determine the significant differences in the values obtained. All statistical analyses were performed using SPSS (version 14.0).

\section{Screening of biosurfactant production}

\section{Results and Discussion}

Three analytical methods were selected for screening of biosurfactant production due to their advantages in terms of simplicity, low cost, and quick implementation. Of 25 isolates screened, five isolates (3M17, 6M1, 10M2, $1 \mathrm{M} 13$ \& 4M5) showed occurrence of clearing zone by the oil spreading technique indicating potential biosurfactant production (Table 1). Isolate 4M5 scored the most positives results by producing the largest diameter of clearing zone of $>1.5 \mathrm{~cm}$, emulsification index of $17 \%$ and the lowest surface tension value at $41.75 \pm 0.54 \mathrm{mN} / \mathrm{m}$.

The oil spreading technique is one of the common method used for detecting biosurfactant production [11]. This technique is more sensitive for biosurfactant detection in the cell-free culture supernatant than other screening methods such as drop collapse [15] and blood haemolysis [16]. The oil spreading technique depends on the decrease in water-oil interfacial tension due to the presence of biosurfactant regardless of its structures [17]. Of five isolates positive for oil spreading technique, it was found that isolate 4M5 produced the largest diameter of clearing zone of more than $1.5 \mathrm{~cm}$, suggesting high biosurfactant concentration in the culture medium. Thavasi et al. [18] showed potential biosurfactant producers produced diameter of clearing zone of $\geq 0.5 \mathrm{~cm}$. Karthik et al. [19], employing oil spreading technique as one of their screening methods, reported a potential biosurfactant-producing microorganism produced diameter of clearing zone in the range of $0.9-2.0 \mathrm{~cm}$, whereas poor biosurfactant producers produced $0.1-0.2 \mathrm{~cm}$.

Emulsification index $\left(\mathrm{E}_{24}\right)$ was employed to investigate the emulsifying properties of biosurfactant. Crude oil was used as the hydrophobic substrate, for isolates capable of releasing surfactant and emulsifying crude oil may have potential application in bioremediation processes of contaminated areas with crude oil. Table 1 showed no emulsification $\left(\mathrm{E}_{24}=0\right)$ when distilled water (negative control) was mixed with crude oil, indicating no surfactant or surfactant-like molecules that may influence the results present in the system. The assumption is that if the cell-free culture supernatant contains biosurfactant, it will then emulsify hydrophobic substrates and maintain stable emulsions for at least 24 hours [20], consequently this method gives just an indication of the presence of biosurfactant. Of 25 isolates screened, only isolates 4M5 and Sf-S5-3 were able to form and maintain stable emulsions with $\mathrm{E}_{24}$ of $17 \%$ and $8 \%$ respectively, while all other isolates that showed negative in oil spreading technique had $\mathrm{E}_{24}=0$ (Table 1).

Emulsification index (17\%) by isolate 4M5 was found to be lower by $30 \%$ compared to Pseudomonas aeruginosa [16] and 36\% compared to Serratia sp [21] used for selection of biosurfactant producers. Karthik et al. [19] reported that an emulsification index ranging from $5.0-75 \%$ was indicative of biosurfactant producers by marine actinobacteria such as Streptomyces, Nocardiopsis and Rhodococcus sp. Isolate Sf-S5-3 on the other hand, may produce an extracellular compound, also known as a bioemulsifier that has emulsifying activity, but it could not effectively reduce the surface tension of culture media, as the diameter of the clearing zone was negative and surface tension value of isolate $\mathrm{Sf}-\mathrm{S} 5-3$ was $55.5 \mathrm{mN} / \mathrm{m}$. 
Table 1. Comparison of three methods for biosurfactant producer

\begin{tabular}{|c|c|c|c|}
\hline Bacterial isolates & $\begin{array}{c}\text { Oil } \\
\text { spreading technique }\end{array}$ & $\begin{array}{l}\text { Surface tension } \\
\qquad(\mathrm{mN} / \mathrm{m})\end{array}$ & $\begin{array}{c}\text { Emulsification index } \\
\left(\% E_{24}\right)\end{array}$ \\
\hline $\operatorname{SDS}(1 \% \mathrm{w} / \mathrm{v})$ & +++ & $32.078 \pm 0.95$ & 81.67 \\
\hline Distilled water & - & $72.0 \pm 0.21$ & 0 \\
\hline MSM only & - & $58.95 \pm 0.3$ & 0 \\
\hline $10 \mathrm{M} 2$ & + & $50.18 \pm 0.62$ & 0 \\
\hline $3 \mathrm{M} 16$ & - & $52.84 \pm 0.55$ & 0 \\
\hline $3 \mathrm{M} 17$ & + & $51.08 \pm 0.53$ & 0 \\
\hline $6 \mathrm{M} 1$ & + & $50.98 \pm 0.42$ & 0 \\
\hline $4 \mathrm{M} 5$ & +++ & $41.75 \pm 0.54$ & 17.04 \\
\hline $5 \mathrm{M} 7$ & - & $57.8 \pm 0.3$ & 0 \\
\hline $7 \mathrm{M} 4$ & - & $55.23 \pm 0.87$ & 0 \\
\hline $1 \mathrm{M} 13$ & + & $49.78 \pm 1.70$ & 0 \\
\hline $7 \mathrm{M} 22$ & - & $53.70 \pm 1.01$ & 0 \\
\hline SF-S11-47 & - & $55.17 \pm 1.11$ & 0 \\
\hline SF-S11-26 & - & $49.49 \pm 0.86$ & 0 \\
\hline SF-S5-9 & - & $56.60 \pm 1.35$ & 0 \\
\hline SF-S5-30 & - & $54.05 \pm 0.43$ & 0 \\
\hline SF-S5-3 & - & $55.50 \pm 0.84$ & 8.33 \\
\hline SF-S10-12 & - & $48.99 \pm 0.42$ & 0 \\
\hline SF-S8-13 & - & $57.33 \pm 1.35$ & 0 \\
\hline SF-S2-5 & - & $57.95 \pm 0.05$ & 0 \\
\hline LF-S11-9 & - & $53.18 \pm 1.24$ & 0 \\
\hline 60 & - & $55.63 \pm 0.51$ & 0 \\
\hline 19 & - & $55.27 \pm 1.12$ & 0 \\
\hline 8 & - & $53.00 \pm 0.61$ & 0 \\
\hline 7 & - & $53.60 \pm 0.72$ & 0 \\
\hline 6 & - & $50.00 \pm 0.2$ & 0 \\
\hline 5 & - & $54.37 \pm 0.72$ & 0 \\
\hline 4 & - & $56.00 \pm 1.98$ & 0 \\
\hline
\end{tabular}

Oil spreading technique '-' clear zone diameter $<0.5 \mathrm{~cm}$ ' + ' clear zone diameter $0.5-0.9 \mathrm{~cm}$; ' ++ ' clear zone diameter $1.0-1.5 \mathrm{~cm}$; ' +++ ' clear zone diameter $>1.5 \mathrm{~cm}$

Quantitative analysis using surface tension measurement additionally supported the biosurfactant production potential of isolate 4M5. It was able to reduce the surface tension of culture medium from 58.95 to $41.75 \mathrm{mN} / \mathrm{m}$. This value is much closer to the surface tension value of $40 \mathrm{mN} / \mathrm{m}$, which was recommended for selection of biosurfactant producer [14]. All other isolates showed surface tension measurements of $>45 \mathrm{mN} / \mathrm{m}$.

A lot of studies related to screening of potential biosurfactant producers rely on surface tension measurement due to its reliability and accuracy in quantifying soluble biosurfactant in the culture medium [15]. Thavasi et al. [18] obtained surface tension values ranging between $30.8-38.75 \mathrm{mN} / \mathrm{m}$ for potential biosurfactant producers among Bacillus species. Surface tension value above $45 \mathrm{mN} / \mathrm{m}$ is regarded as negative for biosurfactant production [22]. 
Since the cell-free culture supernatant of isolate 4M5 was the only isolate that satisfied all three screening methods, it was then selected for identification, determination of the best carbon and nitrogen sources for biosurfactant production and stability studies. Production of extracellular biosurfactant is advantageous from an industrial point of view because product recovery process can be simplified, therefore becoming more economical [23].

Several studies have shown that the use of vegetable oils as the only source of carbon and energy stimulate biosurfactant production by microorganisms. Pseudomonas spp. were reported to produce higher amount of biosurfactant when using sunflower oil compared to other vegetable oil such as olive and corn oil [24], with some strains recorded surface tension value of $<40 \mathrm{mN} / \mathrm{m}$ [25]. Ferraz et al. [26] found that Serratia marcescens produced biosurfactant with surface tension value of $29.75 \mathrm{mN} / \mathrm{m}$, while biosurfactant from Enterococcus strains recorded $68 \%$ reduction in surface tension of culture media [27] when using sunflower oil as the carbon substrate. Vegetable oil contains fatty acids that undergo modification for incorporation into surface active products [28]. Main fatty acid content in sunflower oil is linoleic acid (60\%) [26], thus suggesting that this fatty acid was responsible for stimulating biosurfactant production by isolate $4 \mathrm{M} 5$.

\section{Identification of biosurfactant-producing bacteria}

Gram staining of isolate 4M5 showed that it is a Gram positive, rod-shaped bacterium. The colonies on nutrient agar were cream-coloured, flat, and circular with diameter between $5-6 \mathrm{~mm}$. Biochemical tests revealed that isolate 4M5 is motile, hydrolysed starch and able to break down hydrogen peroxide suggesting the presence of the enzyme catalase. Isolate 4M5 fermented glucose but not sucrose or lactose and able to utilise citrate as its sole carbon source for growth. Biochemical test results for isolate $4 \mathrm{M} 5$ were negative for oxidase enzyme, indole, and $\mathrm{H}_{2} \mathrm{~S}$ production (Table 2). All of these features strongly indicate that isolate 4M5 is Bacillus subtilis. This was further confirmed by analysis of 16S rRNA gene sequences (1212 bp) by BLAST database. The BLAST analysis showed 99\% similar identity with B. subtilis. Isolate 4M5 is now designated Bacillus subtilis UKMP-4M5.

Table 2. Characteristics of isolate 4M5

\begin{tabular}{lclc}
\hline Test & Results & Test & Results \\
\hline Gram reaction & + & Shape & rod \\
Motility & + & Catalase & + \\
Growth at & & Starch hydrolysis & + \\
$20{ }^{\circ} \mathrm{C}$ & - & Methyl red & + \\
$30{ }^{\circ} \mathrm{C}$ & + & Vogues-Proskauer & + \\
$50{ }^{\circ} \mathrm{C}$ & + & $\mathrm{H}_{2} \mathrm{~S}$ production & - \\
$60{ }^{\circ} \mathrm{C}$ & - & Indole & - \\
Triple Sugar Iron & $\mathrm{K} / \mathrm{A}$ & Simmon's citrate & + \\
\hline$+=$ positive, $-=$ negative, & $\mathrm{K} / \mathrm{A}=$ alkaline slant/acidic butt
\end{tabular}

The majority of Gram-positive bacteria capable of producing biosurfactant are from the Bacillus sp. often which was isolated from oil reservoir [29] or soil sample contaminated with petroleum [30]. The genus is reported to produce different types of lipopeptide biosurfactants, such as surfactin, lichenysin, gramicidins and polymyxins. Bacillus subtilis, for example, has been reported to produce three types of lipopeptides, namely surfactin, iturin and fengycin $[1,2]$.

Determination of the best carbon and nitrogen source for biosurfactant production

Production of biosurfactant by B. subtilis UKMP-4M5 has been found to be induced by carbon sources. All five types of carbon sources tested showed a reduction in surface tension of a culture medium (Figure 1). Surface tension values obtained were ranged from $39.7-51.7 \mathrm{mN} / \mathrm{m}$ indicating production of extracellular surface active 
compounds by $B$. subtilis UKMP-4M5 using different carbon sources. There is no significant difference in surface tension value between palm oil and POME. Palm oil was chosen as the best carbon source for biosurfactant production based on the lowest surface tension value at $39.7 \pm 1.23 \mathrm{mN} / \mathrm{m}$, compared to POME which recorded a higher surface tension value at $43.0 \pm 0.84 \mathrm{mN} / \mathrm{m}$.

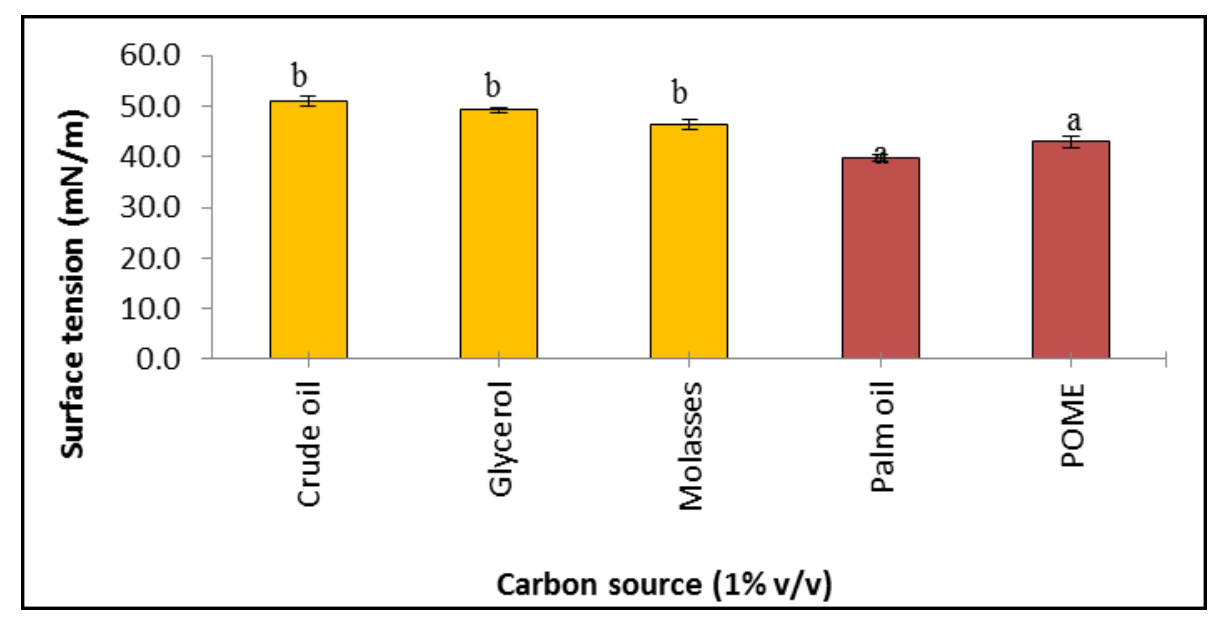

Figure 1. Effect of different carbon sources on the production of biosurfactant by B. subtilis UKMP-4M5. All values are mean of three replicates \pm SD. The letters $a$ and $b$ indicate significant differences $(p<0.05)$ among different carbon sources.

Production of biosurfactant by $B$. subtilis had been reported utilizing mainly water-soluble substrates such as glucose [4], sucrose [31] and glycerol [5]. This is probably due to single-phase fermentation pathway using watersoluble substrate is simpler and thus preferred by microbes than biphasic fermentation [32]. The present study however, showed the ability of $B$. subtilis UKMP-4M5 to produce biosurfactant using various types of carbon sources. Although no experiments on cell growth towards different carbon substrates were conducted, B. subtilis strains were reported to be able to grow and subsequently produce biosurfactants on various carbon substrates tested such as POME [33], glycerol [5], palm oil [34], molasses [7] and crude oil [35]. In the present study, when palm oil was used as a carbon substrate, $B$. subtilis UKMP-4M5 produced biosurfactant with the lowest surface tension value $(39.7 \mathrm{mN} / \mathrm{m}$ ) compared to the other carbon substrates used. This suggests that $B$. subtilis UKMP-4M5 is a lipase positive. This enzyme might be responsible for hydrolysing vegetable oils to produce long chain fatty acids, the important precursors for biosurfactant synthesis [36]. Furthermore, at the same concentrations, vegetable oil can generate more energy than glucose. Other studies have also shown that the use of palm oil as carbon source induced biosurfactant production by $B$. subtilis PT2 [34] and P. aeruginosa FR [37]. A study by Li et al. [36] demonstrated that palm oil was the best carbon source for $P$. aeruginosa GIM32 produced the highest yield of rhamnolipid (30.4 $\mathrm{g} / \mathrm{L}$ ). The use of palm oil as carbon source is advantageous from industrial point of view since it is inexpensive substrates and abundantly available so it can drastically decrease the biosurfactant production cost. Alternative carbon sources from industrial byproducts such as POME can also be effectively used for biosurfactant production by $B$. subtilis UKMP-4M5 since it produces low surface tension values with no significant difference with palm oil. Nevertheless, palm oil produced the lowest surface tension value $(39.7 \mathrm{mN} / \mathrm{m})$ compared to POME $(43.0 \mathrm{mN} / \mathrm{m})$. Crude oil was found to be the least preferred carbon source for biosurfactant production. Crude oil in general contains various components such as saturated hydrocarbons, aromatic compounds, and heavy metals [38] that probably not suitable for enzyme synthesis necessary for biosurfactant production. Haddad et al. [32] reported that crude oil did not support the growth of $B$. subtilis HOB2, thus resulting in a high surface tension value for the culture medium, while Jazeh et al. [35] reported the use of crude oil as carbon substrate supported the growth of B. subtilis and subsequently production of biosurfactant. 
Palm oil was then used to study the biosurfactant production by B. subtilis UKMP-4M5 at various concentrations $(0.5-3 \% \mathrm{v} / \mathrm{v})$. Figure 2 displayed that the highest biosurfactant activity was at $2 \%(\mathrm{v} / \mathrm{v})$ palm oil concentration, with the lowest surface tension value of $35.89 \pm 0.71 \mathrm{mN} / \mathrm{m}$. Further increases in the concentration of palm oil resulted in a significant increase in surface tension measurements.

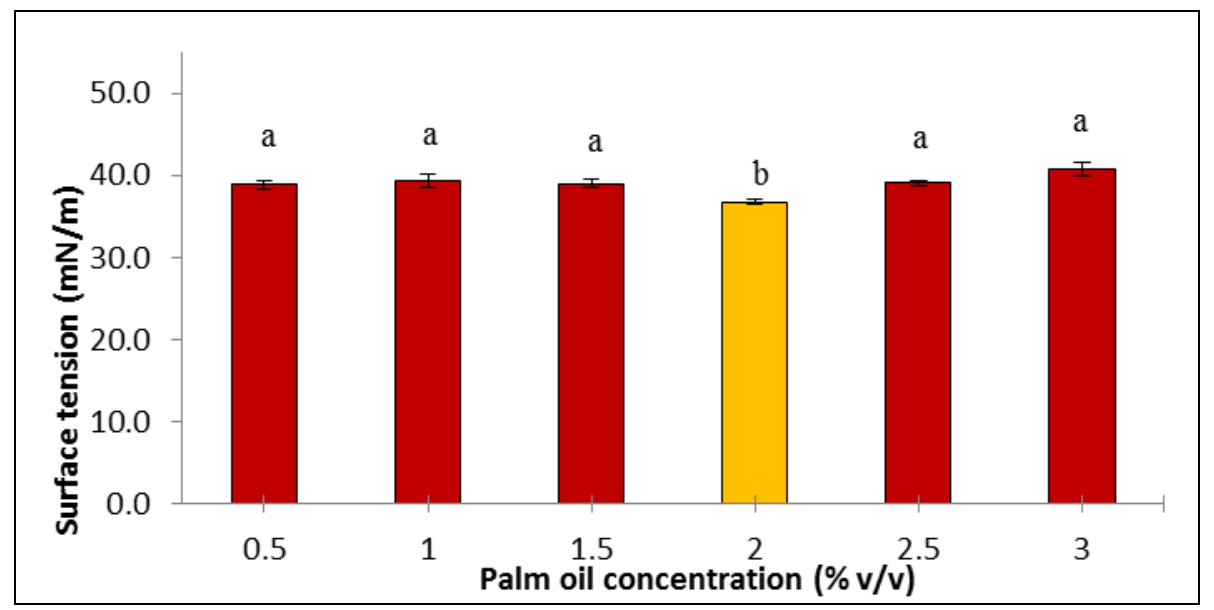

Figure 2. Effect of different concentrations of palm oil on the production of biosurfactant by B. subtilis UKMP4M5. All values are mean of three replicates \pm SD. The letters $a$ and $b$ indicate significant differences $(\mathrm{p}<0.05)$ among different concentration of palm oil.

Pornsunthorntawee et al. [34] also reported in their study that optimum concentration of palm oil for biosurfactant production by $B$. subtilis PT2 was $2 \%(\mathrm{v} / \mathrm{v})$ with maximum surface tension reduction of about $43 \%$. This value is comparable to the percentage obtained in the present study, which was a $40 \%$ surface tension reduction from negative control (surface tension value of $58.89 \mathrm{mN} / \mathrm{m}$ ). P. aeruginosa was also found to produce biosurfactant when using $2 \%(\mathrm{v} / \mathrm{v})$ palm oil as carbon source with surface tension value of $30 \mathrm{mN} / \mathrm{m}$ [39]. Other researchers demonstrated the use of $5 \%(\mathrm{v} / \mathrm{v})$ palm oil as an optimum concentration for maximum production of biosurfactant (30.4 g/L) by P. aeruginosa [37].

Medium constituents such as nitrogen source also affect the production of biosurfactants by B. subtilis UKMP-4M5. In this study, there was no significant difference between yeast extract and ammonium chloride in terms of surface tension reduction (Figure 3). Nevertheless, yeast extract was chosen to be the best nitrogen source as it produced the lowest surface tension value $(35.02 \pm 0.25 \mathrm{mN} / \mathrm{m})$ compared to ammonium chloride $(36.77 \pm 0.71 \mathrm{mN} / \mathrm{m})$.

A study by Pereira et al. [31] also showed yeast extract was found to be the best nitrogen source for optimum biosurfactant production by $B$. subtilis $\# 309$ with surface tension value of $28.73 \pm 0.3 \mathrm{mN} / \mathrm{m}$. A study by Fontes et al. [40] found that the use of yeast extract in combination with ammonium sulphate were the best nitrogen sources for optimum production of biosurfactant by Yarrowia lipolytica (surface tension value of $21.1 \mathrm{mN} / \mathrm{m}$ and $\mathrm{E}_{24}=60.4 \%$ ). For inorganic nitrogen, ammonium chloride was shown to be a better source of nitrogen as opposed to ammonium nitrate for biosurfactant production by B. subtilis UKMP-4M5, though a study by Fonseca et al. [41] showed that ammonium nitrate was the best inorganic nitrogen source for biosurfactant production by $B$. subtilis YRE207. Besides growth, nitrogen plays an important role in biosurfactant production, especially in the lipopeptide biosurfactant as a peptide structure [42].

Effect of different yeast extract concentration $(0.1-0.8 \% \mathrm{w} / \mathrm{v})$ for biosurfactant production by $B$. subtilis UKMP$4 \mathrm{M} 5$ was investigated. An increase in the concentration of yeast extract increases the production of biosurfactant as 
evidenced from reduction in surface tension of culture medium (Figure 4). Although there was no significant difference in the surface tension values for yeast extract concentration between $0.3-0.6 \%(\mathrm{w} / \mathrm{v})$; the lowest surface tension value at $33.6 \pm 0.33 \mathrm{mN} / \mathrm{m}$ was recorded when $0.5 \%(\mathrm{w} / \mathrm{v})$ yeast extract was used. Therefore $0.5 \%(\mathrm{w} / \mathrm{v})$ of yeast extract was chosen to be the best concentration for biosurfactant production rather than $0.3 \%(\mathrm{w} / \mathrm{v})$ of yeast extract (higher surface tension value recorded at $35.9 \pm 1.1 \mathrm{mN} / \mathrm{m}$ ). An increase in the concentration of yeast extract beyond $0.6 \%(\mathrm{w} / \mathrm{v})$ resulted in the increase of surface tension values significantly, indicating less biosurfactant production by the test bacterium.

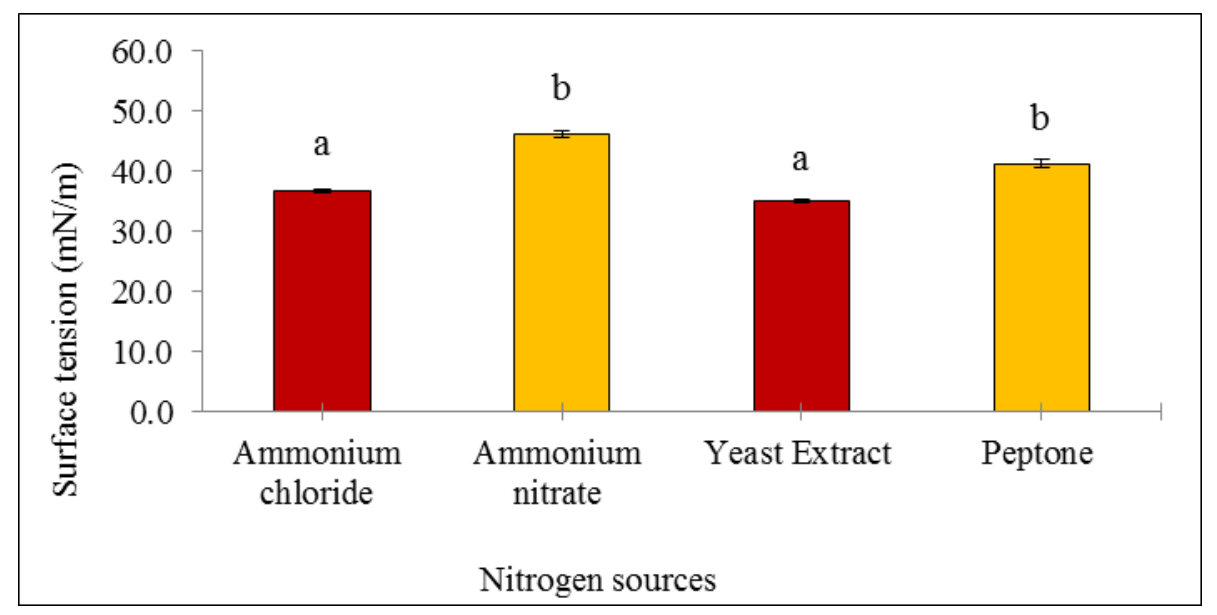

Figure 3. Effect of different nitrogen sources on the production of biosurfactant by B. subtilis UKMP-4M5. All values are mean of three replicates $\pm \mathrm{SD}$. The letters $\mathrm{a}$ and $\mathrm{b}$ indicate significant differences $(\mathrm{p}<0.05)$ among different nitrogen sources.

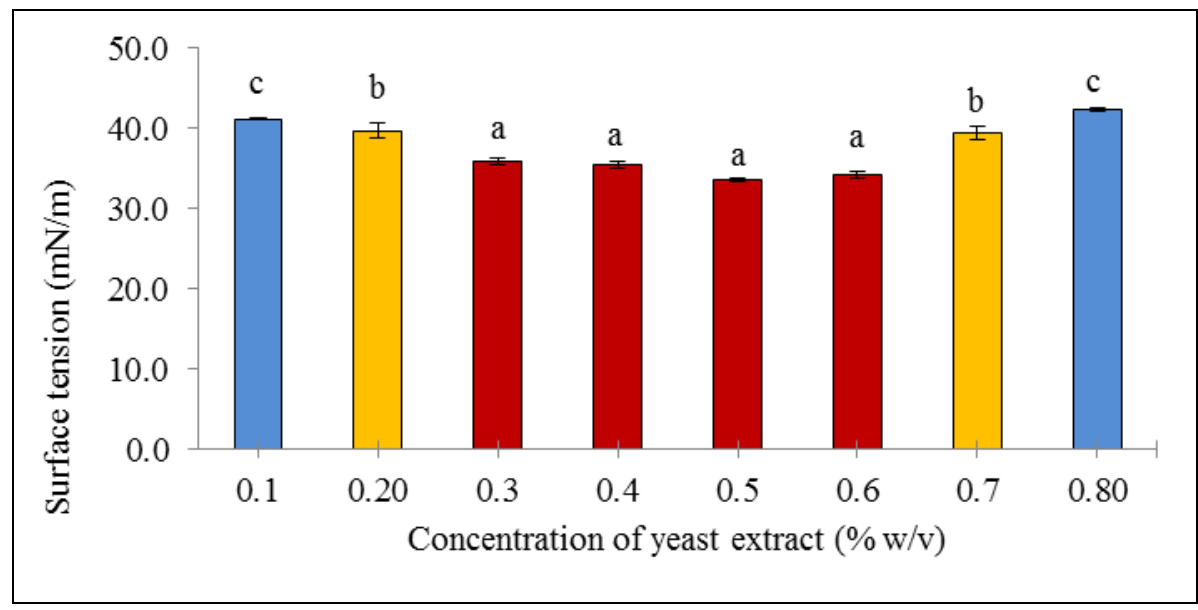

Figure 4. Effect of different concentrations of yeast extract on the production of biosurfactant by B. subtilis UKMP$4 \mathrm{M} 5$. All values are mean of three replicates $\pm \mathrm{SD}$. The letters $\mathrm{a}, \mathrm{b}$, and $\mathrm{c}$ indicate significant differences $(\mathrm{p}<0.05)$ among concentrations of yeast extract. 
Bacillus subtilis UKMP-4M5 was found to produce biosurfactant with the lowest surface tension value of $35.02 \pm$ $0.25 \mathrm{mN} / \mathrm{m}$ when using $0.5 \%(\mathrm{w} / \mathrm{v})$ yeast extract. Similar results were shown by Vedaraman \& Venkatesh [43] whereby the use of $0.5 \%(\mathrm{w} / \mathrm{v})$ yeast extract was optimum for surfactin production $(983 \mathrm{mg} / \mathrm{L})$ by $B$. subtilis MTC2423. Rashedi et al. [44] reported in their study that the use $0.5 \%(\mathrm{w} / \mathrm{v})$ yeast extract in combination with $0.5 \%$ $(\mathrm{w} / \mathrm{v})$ soy flour were the best nitrogen sources for optimal production of rhamnolipid $(3.7 \mathrm{~g} / \mathrm{L})$ by $P$. aeruginosa. A study by Nalini et al. [6] reported the use of $0.3 \%(\mathrm{w} / \mathrm{v})$ yeast extract was optimal for biosurfactant production by Bacillus $s p$ grown in a glucose-containing medium, while Pereira et al. [31] used $0.2 \%(\mathrm{w} / \mathrm{v})$ yeast extract for biosurfactant production by $B$. subtilis \#309 when grown in sucrose-containing medium. Fontes et al. [32] on the other hand, used a combination of $0.05 \%(\mathrm{w} / \mathrm{v})$ yeast extract and $10 \mathrm{~g} / \mathrm{L}$ ammonium sulphate to obtain optimum production of biosurfactant by $Y$. lipolytica, with surface tension value of $20.9 \mathrm{mN} / \mathrm{m}$ and emulsification index of $73.1 \%$. The present study showed $0.3 \%(\mathrm{w} / \mathrm{v})$ yeast extract was enough to produce biosurfactant with significant reduction in the surface tension value; however, $0.5 \%(\mathrm{w} / \mathrm{v})$ produced the lowest surface tension value. The increase in surface tension value with further increase in yeast extract concentration (beyond $0.6 \% \mathrm{w} / \mathrm{v}$ ) may be due to nitrogen-limiting conditions no longer being a factor in biosurfactant biosynthesis. Some studies reported that biosurfactant production is more efficient under nitrogen-limiting conditions [36].

The best conditions for biosurfactant production by B. subtilis UKMP-4M5 were using $2 \%(\mathrm{v} / \mathrm{v})$ palm oil and $0.5 \%$ $(\mathrm{w} / \mathrm{v})$ yeast extract as carbon and nitrogen sources respectively as it produced the lowest surface tension value at $33.6 \pm 0.33 \mathrm{mN} / \mathrm{m}$.

\section{Stability studies}

Biosurfactant activity was tested over a range of $\mathrm{pH}$ values $(2-12)$. Results showed the activity of biosurfactant was greatly affected by changes in $\mathrm{pH}$. Low biosurfactant activity was detected at extreme $\mathrm{pH} ; 2$ to 4 and above 10 (Figure 5). Surface tension values remained relatively stable between $\mathrm{pH} 6$ to 8 with no significant difference; however the lowest surface tension value was achieved at $\mathrm{pH} 6$. The result also showed that highly acidic $\mathrm{pH}$ caused a greater reduction in surface activity than highly alkaline $\mathrm{pH}$ (surface tension value of $38.77 \mathrm{mN} / \mathrm{m}$ at $\mathrm{pH} 2$ as opposed to $36.9 \mathrm{mN} / \mathrm{m}$ at $\mathrm{pH} 12$ ).

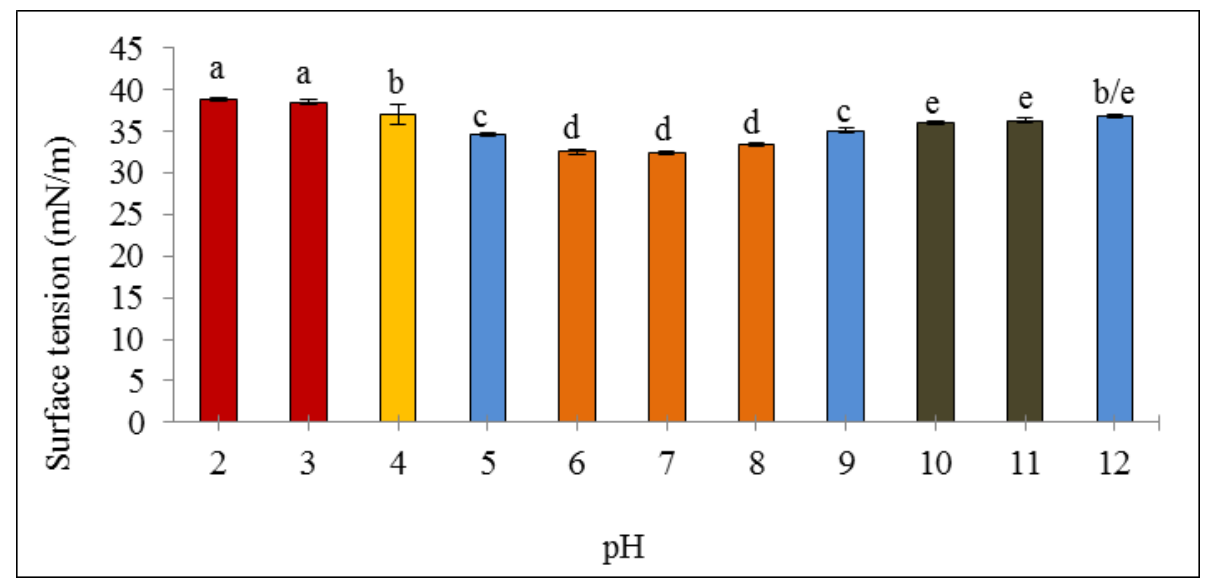

Figure 5. Effect of $\mathrm{pH}$ on biosurfactant activity produced by $B$. subtilis UKMP-4M5. All values are mean of three replicates $\pm \mathrm{SD}$. The letters $\mathrm{a}, \mathrm{b}, \mathrm{c}, \mathrm{d}$, and e indicate significant differences $(\mathrm{p}<0.05)$ among different $\mathrm{pH}$.

$\mathrm{pH}$ values between 2 to 4 showed a significant decrease in biosurfactant activity as shown by the increase in surface tension values. These results are in accordance with those reported by Vaz et al. [45], whereby biosurfactant stability from B. subtilis EG1 was found to be unstable by acidic pH. Abdel-Mawgoud et al. [7] also reported similar findings in their study in which surfactin activity started to decrease at $\mathrm{pH}<5$, samples become turbid due partial precipitation of biosurfactant in acidic conditions. The test biosurfactant showed better stability at alkaline 
than acidic conditions, as shown by lower surface tension values when incubated in alkaline conditions as compared to acidic conditions. Similar results reported by El-Sersy [8] indicated that biosurfactant from B. subtilis N10 was found to have high surface activity predominantly in the alkaline condition, $\mathrm{pH}$ between $6.0-12$. Abdel-Mawgoud et al. [7] reported that surfactin from B. subtilis was soluble in aqueous solutions at $\mathrm{pH}$ values higher than 5.0 with optimum solubility at $\mathrm{pH}$ 8.0-8.5. This could be due to the acidic nature of surfactin, as the presence of two carboxylic groups from glutamic and aspartic acid residues confers an anionic nature [7]. Similar results had been reported for biosurfactant production from other microorganisms such as P. aeruginosa [14], which was stable at a wide range of $\mathrm{pH}$ between 6.0-10.0, whereas stability of biosurfactant from Nocardiopsis sp. was found to be stable between $\mathrm{pH} 8-12$ [46].

Thermal stability of biosurfactant was investigated over a wide temperature range $\left(10-100{ }^{\circ} \mathrm{C}\right)$ for 1 hour and cooled to room temperature. Results showed that the biosurfactant from B. subtilis UKMP-4M5 exhibited excellent surface activity with no significant difference $(\mathrm{p}>0.05)$ of the temperature tested (Figure 6). Surface activity remained relatively stable with surface tension values between $32.47-33.10 \mathrm{mN} / \mathrm{m}$ even after exposure to high temperature $\left(100^{\circ} \mathrm{C}\right)$. Interestingly, the test biosurfactant retained its surface activity even after autoclaving, with a negligible increase in surface tension value $(0.67 \mathrm{mN} / \mathrm{m}$ ) before and after autoclaving (Figure 7), suggesting that no degradation occurred.

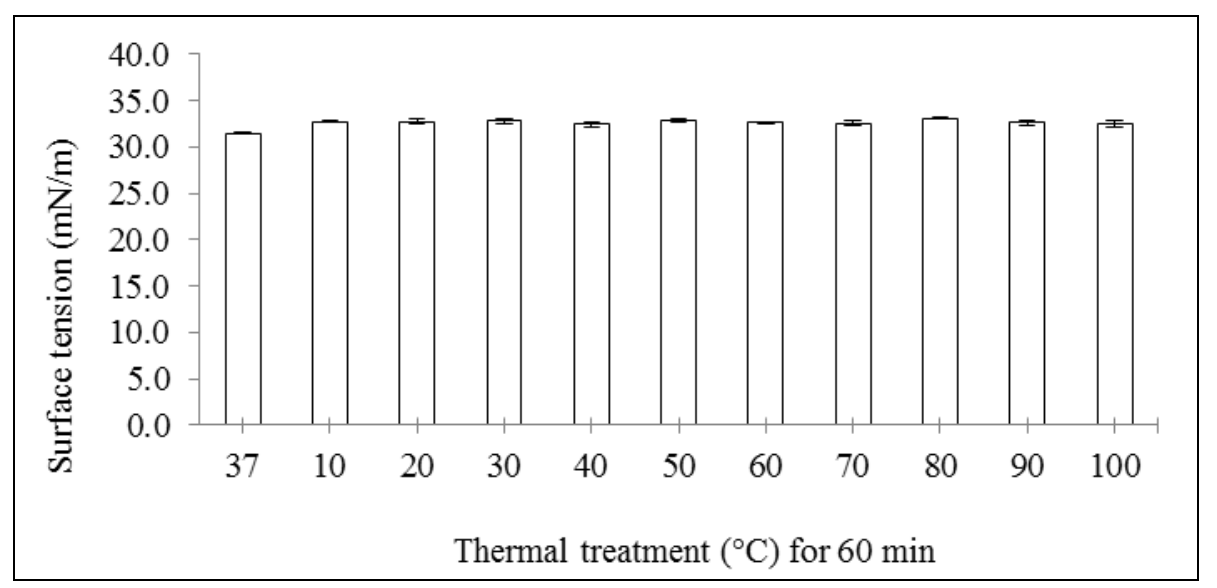

Figure 6. Effect of temperature on biosurfactant activity produced by B. subtilis UKMP-4M5. All values are mean of three replicates $\pm \mathrm{SD}$.

Thermal stability studies of biosurfactant from $B$. subtilis UKMP-4M5 indicated that the surfactant was thermostable, as heating up to $100{ }^{\circ} \mathrm{C}$ caused no significant effect on the biosurfactant performances. The high thermal stability of the test biosurfactant is on par with other synthetic surfactants such as linear alkylbenzene sulfonate (LAS) and alkylpolyglucoside [45], but superior to sodium dodecyl sulphate, which exhibits a significant loss of activity at temperatures above $70{ }^{\circ} \mathrm{C}$ [46]. Interestingly, the test biosurfactant retained its surface activity even after autoclaving at $121{ }^{\circ} \mathrm{C}$ for $20 \mathrm{~min}$, suggesting its potential application in food, pharmaceutical and cosmetic industries where heating to achieve sterility are important. Biosurfactants from B. subtilis have been reported to exhibit excellent thermal stability. Surfactin for example showed no change in surface tension value before and after heating treatment at $100^{\circ} \mathrm{C}$, though slight increase was observed at $121^{\circ} \mathrm{C}$ for $10 \mathrm{~min}$. This may be due to precipitation of heat-dependent substances such as proteins contaminating the surfactin solution which might have been co-extracted during the extraction steps [7]. Haddad et al. [32] investigated the stability of biosurfactant from a $B$. subtilis strain at $100{ }^{\circ} \mathrm{C}$ at different exposure time. The authors reported that no interference on the surface activity could be found, thus corroborating the results obtained in the current study. Results from the current study have thus illustrated the stability of biosurfactant produced by B. subtilis UKMP-4M5 at high temperatures which may be encountered in oil fields. 


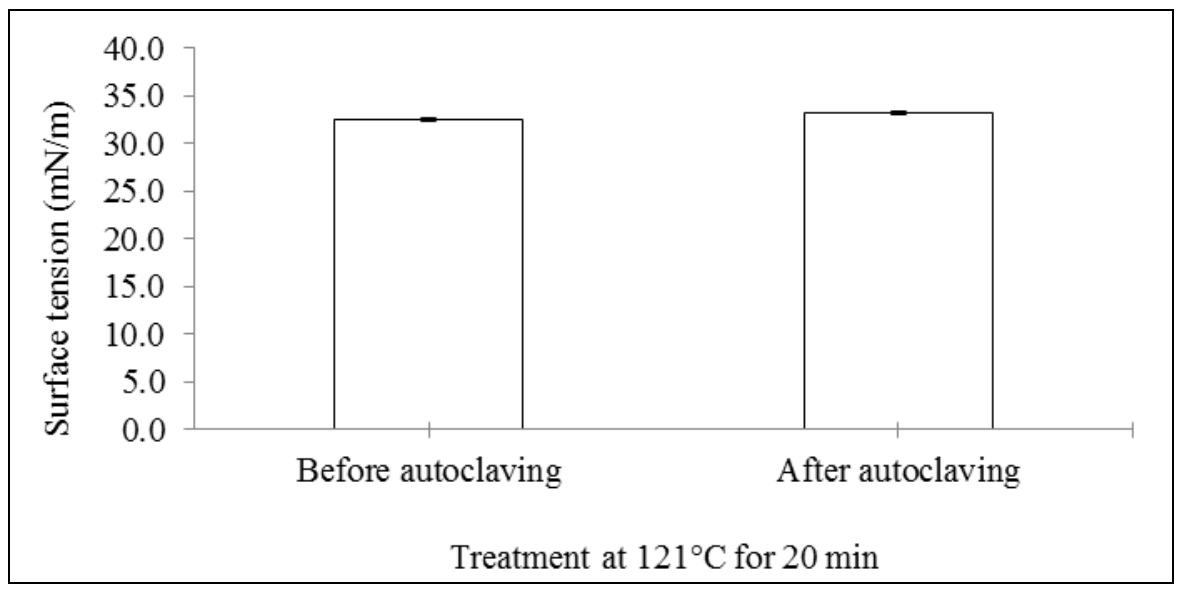

Figure 7. Effect of autoclaving on biosurfactant activity produced by B. subtilis UKMP-4M5. All values are mean of three replicates $\pm \mathrm{SD}$.

The effect of different $\mathrm{NaCl}$ concentrations $(1-15 \% \mathrm{w} / \mathrm{v})$ on biosurfactant activity from $B$. subtilis UKMP-4M5 was studied to evaluate its potential application in bioremediation of contaminated marines. Figure 8 shows that the changed in surface tension value of the tested biosurfactant was not significant between $1-5 \%(\mathrm{w} / \mathrm{v}) \mathrm{NaCl}$ concentrations. Optimum stability of biosurfactant was observed at $3 \%(\mathrm{w} / \mathrm{v}) \mathrm{NaCl}$ with the lowest surface tension value at $33.18 \mathrm{mN} / \mathrm{m}$.

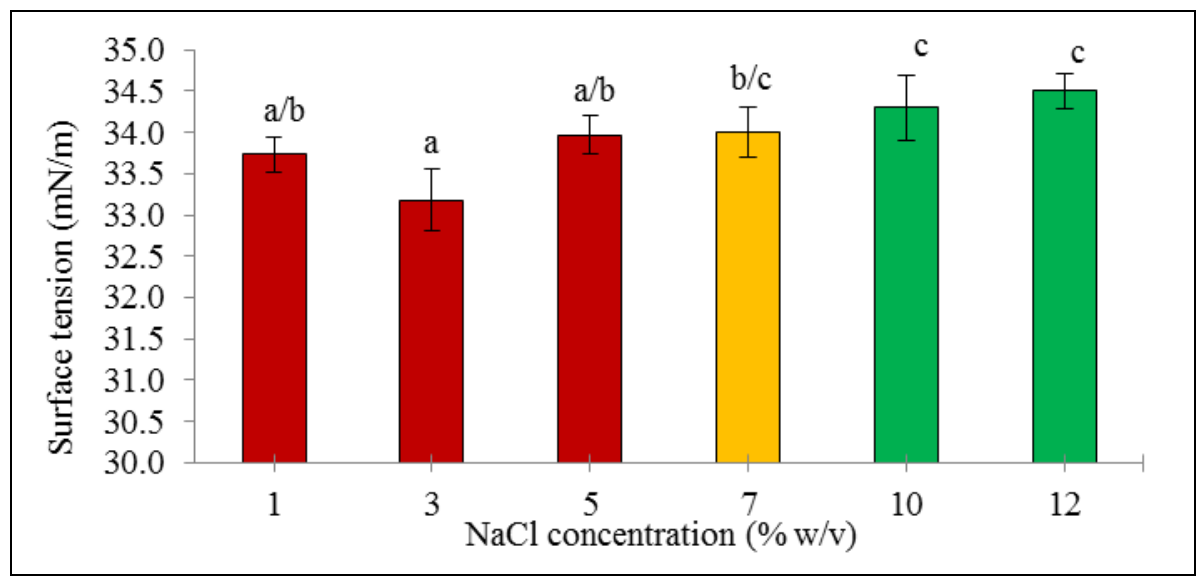

Figure 8. Effect of $\mathrm{NaCl}$ concentration on biosurfactant activity produced by B. subtilis UKMP-4M5. All values are mean of three replicates $\pm \mathrm{SD}$. The letters $\mathrm{a}, \mathrm{b}$, and $\mathrm{c}$ indicate significant differences $(\mathrm{p}<0.05)$ among $\mathrm{NaCl}$ concentrations

The addition of $\mathrm{NaCl}$ in the range tested had a weak effect on the surface tension of biosurfactant produced by B. subtilis UKMP-4M5. Stability of biosurfactant from B. subtilis had been reported to be excellent in the presence of $\mathrm{NaCl}$ up to $20 \%$ (w/v) [8]. Ghojavand et al. [29], who reported that $\mathrm{NaCl}$ concentration, did not affect the surface activity of biosurfactant from $B$. subtilis PTCC 1696, the highest surface tension value recorded at $34 \mathrm{mN} / \mathrm{m}$ at $20 \%$ (w/v) NaCl. Similarly, Haddad et al. [32] reported that $25 \%$ (w/v) $\mathrm{NaCl}$ concentration showed only slight variation in the surface tension value $(4 \mathrm{mN} / \mathrm{m})$ of biosurfactant from $B$. subtilis HOB2. The stability of the biosurfactant 
obtained from the present study is shown to be superior to other strain of $B$. subtilis which was reported to be losing its surface activity (surface tension value at $45 \mathrm{mN} / \mathrm{m}$ ) when level of $\mathrm{NaCl}$ reached $11 \%(\mathrm{w} / \mathrm{v})$ [5]. These findings have revealed that the tested biosurfactant had a high level of tolerance to ionic strength, and is thus an excellent candidate if compared with chemical surfactants for use in bioremediation of contaminated marine environments. Chemical surfactants, however, are deactivated by $2-3 \%$ salt concentrations [47].

\section{Conclusion}

In the present study, a bacterial isolate identified as B. subtilis UKMP-4M5 was found to be the most potential biosurfactant producer. This isolate can produce biosurfactant using $2 \%(\mathrm{v} / \mathrm{v})$ palm oil with addition of yeast extract with low surface tension value. The semi purified biosurfactant is thermostable to extreme temperatures. Furthermore, the test biosurfactant has proved to be robust and stable over huge ranges of $\mathrm{pH}$ and salinity. Thus, the biosurfactant has great potential for commercial use in industries such as enhanced oil recovery, bioremediation, and food-related industries as an alternative to the synthetic surfactants. Further work is required to fully characterise the biosurfactant to better predict its potential applications.

\section{Acknowledgement}

The authors would like to express gratitude to Universiti Kebangsaan Malaysia for providing grant UKM-ST-06FRGS0098-2009.

\section{References}

1. Muthusamy, K., Gopalakrishnan, S., Ravi, T. K. and Sivachidambaram, P. (2008). Biosurfactants: Properties, commercial production and application. Current Science, 94(6): 736 - 747.

2. Kim, P. I. I., Ryu, J., Kim, Y. H. and Chi, Y-T. (2010). Production of biosurfactant lipopeptides iturin A, fengycin, and surfactin A from Bacillus subtilis CMB32 for control of Colletotrichum gloeosporioides. Journal of Microbiology and Biotechnology, 20(1): 138 - 145.

3. Lee, S-C., Kim, S-H., Park, I-H., Chung, S-Y., Chandra, M. S. and Choi, Y-L. (2010). Isolation, purification, and characterization of novel fengycin S from Bacillus amyloliquefaciens LSC04 degrading crude oil. Biotechnology and Bioprocess Engineering, 15: 246 - 253.

4. Chander, C. R. S., Lohitnath, T., Kumar, D. J. M. and Kalaichelvan, P. T. (2012). Production and characterization of biosurfactant from Bacillus subtilis MTCC441 and its evaluation to use as bioemulsifier for food bio-preservative. Advances in Applied Science Research, 3(3): 1827 - 1831.

5. Simmai, A., Rukadee, O., Sohbon, V. and Manerat, S. (2012). Biosurfactant production by Bacillus subtilis TD4 and Pseudomonas aeruginosa SU7 grown on crude glycerol obtained from biodiesel production plant as sole carbon source. Journal of Scientific and Industrial Research, 71: 396 - 406.

6. Nalini, S., Parthasarathi, R. and Thandapani, C.M. (2013). Isolation, screening and characterization of biosurfactant produced by Bacillus sp. from automobile oil contaminated soil. International Journal of Pharmaceutical \& Biological Archives, 4(1): 130 - 135.

7. Abdel-Mawgoud, A. M., Aboulwafa, M. M. and Hassouna, N. A. H. (2008). Characterization of surfactin produced by Bacillus subtilis isolate BS5. Applied Biochemistry and Biotechnology, 150(3): 289-303.

8. El-Sersy, N.A. (2012). Plackett-Burman design to optimize biosurfactant production by marine Bacillus subtilis N10. Romanian Biotechnological Letter, 17(2): 7049 - 7064.

9. Hamzah A., Rabu, A., Azmy, R. F. H. R. and Yussoff, N. A. (2010). Isolation and characterization of bacteria degrading sumandak and South and Angsi oils. Sains Malaysiana, 39(2): $161-168$.

10. Zajic, E. and Supplison, B. (1972). Emulsification and degradation of "Bunker C" fuel oil by microorganisms. Biotechnology and Bioengineering, 14: 331 - 334.

11. Youssef, N. H., Duncan, K. E., Nagle, D. P., Savage, K. N., Knapp, R. M. and Mcinerney, M. J. (2004). Comparison of methods to detect biosurfactant production by diverse microorganisms. Journal of Microbiological Methods, 56: 339 - 347.

12. Cooper, D. and Goldenberg, B. (1987). Surface-active agents from two Bacillus species. Applied Environmental Microbiology, 53(2): $224-229$.

13. Bodour, A. A. and Miller-Maier, R. M. (1998). Application of a modified drop-collapse technique from surfactant quantitation and screening of biosurfactant-producing microorganisms. Journal of Microbiological Methods, 32: 273 - 280. 
14. Techaoei, S., Lumyong, S., Prathumpai, W., Santiarwarn, D. and Leelapornspisid, P. (2011). Screening characterization and stability of biosurfactant produced by Pseudomonas aeruginosa SCMU106 isolated from soil in Northern Thailand. Asian Journal of Biological Sciences, 4(4): 340 - 351.

15. Hamzah, A., Sabturani, N. and Radiman, S. (2013). Screening and optimization of biosurfactant production by the hydrocarbon-degrading bacteria. Sains Malaysiana, 42(5): 615 - 623.

16. Varjani, S. J., Rana, D. P., Bateja, S., Sharma, M. C. and Upasani, V. N. (2014). Screening and identification of biosurfactant (bioemulsifier) producing bacteria from crude oil contaminated sites of Gujarat India. International Journal of Innovative Research in Science, Engineering and Technology, 3(2): 9205 - 9213.

17. Morikawa, M., Hirata, Y. and Imanaka, T. (2000). A study on the structure-function relationship of lipopeptide biosurfactant. Biochemical and Biophysics Acta, 1488(3): 211 - 218.

18. Thavasi, R., Sharma, S. and Jayalakshmi, S. (2011). Evaluation of screening methods for the isolation of biosurfactant producing marine bacteria. Journal of Petroleum and Environmental Biotechnology. S1: $1-6$.

19. Karthik, L., Kumar, G. and Rao, K.V.B. (2010). Comparison of methods and screening of biosurfactant producing marine actinobacteria isolated from Nicobar marine sediment. The IIOAB Journal, 9(2): $34-38$.

20. Shoeb, E., Ahmed, N., Akhter, J., Badar, U., Siddiqui, K., Ansari, F. A., Waqar, M., Imtiaz, S., Akhtar, N., Shaikh, Q. A., Baig, R., Butt, S., Khan, S., Khan, S., Hussain, S., Ahmed, B. and Ansari, M. (2015). Screening and characterization of biosurfactant-producing bacteria isolated from the Arabian Sea coast of Karachi. Turkish Journal of Biology. 39: 210 - 216.

21. Nishanthi, R., Kumaran, S., Palani, P., Chellaram, C., Anan, T. P. and Kannan, V. (2011). Screening of biosurfactants from hydrocarbon degrading bacteria. Journal of Ecobiotechnology. 2(5): 47 - 53.

22. Viramontes-Ramos, S., Portillo-Ruiz, M. C., Ballinas-Casarrubias, M. L., Torres-Munoz, J.V., Rivera-Chavira, B. E. and Nevarez-Moorillon, G.V. (2010). Selection of biosurfactant/bioemulsifier-producing bacteria from hydrocarbon-contaminated soil. Brazilian Journal of Microbiology, 41: 668 - 675.

23. Safary, A., Ardakani, M. R., Suraki, A. A., Khiavi, M. A. and Motamedi, H. (2010). Isolation and characterization of biosurfactant producing bacteria from Caspian Sea. Biotechnology, 9(3): $378-382$.

24. Cerqueira dos Santos, S., Fernandez, L. G., Rossi-Alva, J. C. and de Abreu Roque, M. R. (2010). Evaluation of substrates from renewable-resources in biosurfactants production by Pseudomonas strains. African Journal of Biotechnology, 9(35): $5704-5711$.

25. Haba, E., Espuny, M. J., Busquets, M. and Manresa, A. (2000). Screening and production of rhamnolipids by Pseudomonas aeruginosa 47T2 NCIB 40044 from waste frying oils. Journal of Applied Microbiology. 88: 379 $-387$.

26. Ferraz, C., De Araujo, A. A. and Pastore, G. M. (2002). The influence of vegetable oils on biosurfactant production by Serratia marcescens. Applied Biochemistry and Biotechnology, 98(1): $841-847$.

27. Jadhav, M., Kagaikar, A., Jadhav, S. and Govindwar, S. (2011). Isolation, characterization and antifungal application of a biosurfactant produced by Enterobacter sp. MS16. European Journal of Lipid, Science and Technology, 113(11): $1347-1358$.

28. Banat, I. M., Satpute, S. K., Cameotra, S. S., Patil, R. and Nyayanit, N. V. (2014). Cost effective technologies and renewable substrates for biosurfactants' production. Frontier in Microbiology, 5: 697 - 715.

29. Ghojavand, H., Vahabzadeh, F., Roayaei, E. and Shahraki, A. K. (2008). Production and properties of a biosurfactant obtained from a member of the Bacillus subtilis group (PTCC 1696). Journal of Colloid and Interface Science. 324: 172 - 176.

30. Joshi, S. J., Suthar, H., Yadav, A. K., Kingurao, K. and Nerurkar, A. (2013). Occurrence of biosurfactant producing Bacillus spp. in diverse habitats. ISRN Biotechnology, 2013: 1 -6.

31. Pereira, J. F. B., Gudina, E. J., Costa, R., Vitorino, R., Teixeira, J. A., Coutinho, J. A. P. and Rodrigues, L. R. (2013). Optimization and characterization of biosurfactant production by Bacillus subtilis isolates towards microbial enhanced oil recovery applications. Fuel, 111:259- 268.

32. Haddad, N. I. A., Wang, J. and Mu, B. (2009). Identification of a biosurfactant producing strain: Bacillus subtilis HOB2. Protein and Peptide Letters. 16: 7 - 13.

33. Abas, M. R., Kader, A. J. A., Khalil, M. S., Hamid, A. A. and Isa, M. H. M. (2013). Production of surfactin from Bacillus subtilis ATCC 21332 by using treated palm oil mill effluent (POME) as fermentation media. International Conference on Food and Agricultural Sciences, 55: 87 - 93. 
34. Pornsunthorntawee, O., Arttaweeporn, N., Paisanjit, S., Somboonthanate, P., Abe, M., Rujiravanit, R. and Chavadej, S. (2008). Isolation and comparison of biosurfactants produced by Bacillus subtilis PT2 and Pseudomonas aeruginosa SP4 for microbial surfactant-enhanced oil recovery. Biochemical Engineering Journal, 42: 172 - 179.

35. Jazeh, G., Forghani, F. and Oh, D-H. (2012). Biosurfactant production by Bacillus sp. isolated from petroleum contaminated soils of Sirri Island. American Journal of Applied Sciences, 9(1): $1-6$.

36. Li, A-H., Xu, M-Y., Sun, W. and Sun, G-P. (2010). Rhamnolipid production by Pseudomonas aeruginosa GIM 32 using different substrates including molasses distillery wastewater. Applied Biochemistry and Biotechnology, 163(5): $600-611$.

37. Oliveira, F.J.S., Vazquez, L., Campos, N.P. and Franca, F.P. (2007). Biosurfactant production by Pseudomonas aeruginosa RF using palm oil. Applied Biochemistry and Biotechnology, 129 - 132: 727 - 737.

38. Abalos, A., Vinas, M., Sabate, J., Manresa, M. A. and Solanas, A. M. (2004). Enhanced biodegradation of Casablanca crude oil by a microbial consortium in presence of a rhamnolipid produced by Pseudomonas aeruginosa AT10. Biodegradation, 15: 249 - 260.

39. Thaniyavarn, J., Chongchin, A., Wanitsuksombut, N., Thaniyavarn, S., Pinphanichakarn, P., Leepipatpiboon, N., Morikawa, M. and Kanaya, S. (2006). Biosurfactant production by Pseudomonas aeruginosa A41 using palm oil as carbon source. Journal of General Applied Microbiology, 52: 215 - 222.

40. Fontes, G. C., Amaral, P. F. F., Nele, M. and Coelho, M. A. Z. (2010). Factorial design to optimize biosurfactant production by Yarrowia lipolytica. Journal of Biomedicine and Biotechnology, 2010: $1-8$.

41. Fonseca, R. R., Silva, A. J. R., De Franca, F. P., Cardoso, V. L. and Servulo, E. F. C. (2007). Optimizing carbon/nitrogen ratio for biosurfactant production by a Bacillus subtilis strain. Applied Biochemistry and Biotechnology. 137(1): $471-486$.

42. Nawawi, W. M. W., Jamal, P. and Alam, M. Z. (2010). Utilization of sludge palm oil as a novel substrate for biosurfactant production. Bioresource Technology, 101: 9241 - 9247.

43. Vedaraman, N. and Venkatesh, N. (2011). Production of surfactin by Bacillus subtilis MTCC 2423 from waste frying oils. Brazilian Journal of Chemical Engineering. 28(02): 175 - 180.

44. Rashedi, H., Azadi, M. M., Jamshidi, E. and Bonakdarpour, B. (2006). Production of rhamnolipids by Pseudomonas aeruginosa growing on carbon sources. International Journal of Environmental Science and Technology, 3(3): 297 - 303.

45. Vaz, D. A., Gudina, E. J., Alameda, E. J., Teixeira, J. A. and Rodrigues, L. R. (2012). Performance of a biosurfactant produced by a Bacillus subtilis strain isolated from crude oil samples as compared to commercial chemical surfactants. Colloids and Surfaces B:Biointerfaces, 89: $167-174$.

46. Khopade, A., Biao, R., Liu, X., Mahadik, K., Zhang, L. and Kokare, C. (2012). Production and stability studies of the biosurfactant isolated from marine Nocardiopsis sp. B4. Desalination. 285: $198-204$.

47. Bognolo, G. (1999). Biosurfactants as emulsifying agents for hydrocarbons. Colloids Surfaces A: Physicochemical Engineering Aspects. 152(1): 41 - 52. 